University of Nebraska - Lincoln

DigitalCommons@University of Nebraska - Lincoln

\title{
Influence of Carbon and Lipid Sources on Variation of Mercury And Other Trace Elements in Polar Bears (Ursus Maritimus)
}

Heli Routti

National Wildlife Research Centre, heli.routti@npolar.no

Robert J. Letcher

National Wildlife Research Centre, robert.letcher@ec.gc.ca

Erik W. Born

Greenland Institute of Natural Resources

Marsha Branigan

Government of the Northwest Territories

Rune Dietz

Aarhus University, rdi@dmu.dk

See next page for additional authors

Follow this and additional works at: https://digitalcommons.unl.edu/usfwspubs

Routti, Heli; Letcher, Robert J.; Born, Erik W.; Branigan, Marsha; Dietz, Rune; Evans, Thomas J.; Mckinney, Melissa A.; Peacock, Elizabeth; and Sonne, Christian, "Influence of Carbon and Lipid Sources on Variation of Mercury And Other Trace Elements in Polar Bears (Ursus Maritimus)" (2012). US Fish \& Wildlife Publications. 385.

https://digitalcommons.unl.edu/usfwspubs/385

This Article is brought to you for free and open access by the US Fish \& Wildlife Service at DigitalCommons@University of Nebraska - Lincoln. It has been accepted for inclusion in US Fish \& Wildlife Publications by an authorized administrator of DigitalCommons@University of Nebraska - Lincoln. 


\section{Authors}

Heli Routti, Robert J. Letcher, Erik W. Born, Marsha Branigan, Rune Dietz, Thomas J. Evans, Melissa A. Mckinney, Elizabeth Peacock, and Christian Sonne 


\title{
Environmental Chemistry
}

\section{INFLUENCE OF CARBON AND LIPID SOURCES ON VARIATION OF MERCURY AND OTHER TRACE ELEMENTS IN POLAR BEARS (URSUS MARITIMUS)}

\author{
Heli Routti, $\dagger \ddagger$ Robert J. Letcher, $* \dagger$ Erik W. Born, $§$ Marsha Branigan, $\|$ Rune Dietz,\# Thomas J. Evans, $\dagger \dagger$ \\ Melissa A. McKinney, $\dagger$ Elizabeth Peacock, $\nmid \dagger$ and Christian Sonne\# \\ $\dagger$ Ecotoxicology and Wildlife Health Division, Science and Technology Branch, Environment Canada, National Wildlife Research Centre, \\ Carleton University, Ottawa, Ontario \\ $\ddagger$ Norwegian Polar Institute, Fram Centre, Tromsø, Norway \\ $\S$ Greenland Institute of Natural Resources, Nuuk, Greenland \\ ||Department of Environment and Natural Resources, Government of the Northwest Territories, Inuvik, Northwest Territories, Canada \\ \#Department of Bioscience, Faculty of Science and Technology, Aarhus University, Roskilde, Denmark \\ ††United States Fish and Wildlife Service, Anchorage, Alaska

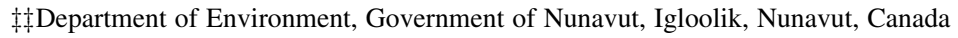

(Submitted 8 May 2012; Returned for Revision 13 June 2012; Accepted 1 July 2012)

\begin{abstract}
In the present study, the authors investigated the influence of carbon and lipid sources on regional differences in liver trace element ( $\mathrm{As}, \mathrm{Cd}, \mathrm{Cu}$, total $\mathrm{Hg}, \mathrm{Mn}, \mathrm{Pb}, \mathrm{Rb}, \mathrm{Se}$, and $\mathrm{Zn}$ ) concentrations measured in polar bears (Ursus maritimus) $(n=121)$ from 10 Alaskan, Canadian Arctic, and East Greenland subpopulations. Carbon and lipid sources were assessed using $\delta^{13} \mathrm{C}$ in muscle tissue and fatty acid (FA) profiles in subcutaneous adipose tissue as chemical tracers. A negative relationship between total $\mathrm{Hg}$ and $\delta^{13} \mathrm{C}$ suggested that polar bears feeding in areas with higher riverine inputs of terrestrial carbon accumulate more $\mathrm{Hg}$ than bears feeding in areas with lower freshwater input. Mercury concentrations were also positively related to the FA 20:1n-9, which is biosynthesized in large amounts in Calanus copepods. This result raises the hypothesis that Calanus glacialis are an important link in the uptake of $\mathrm{Hg}$ in the marine food web and ultimately in polar bears. Unadjusted total $\mathrm{Hg}$, Se, and As concentrations showed greater geographical variation among polar bear subpopulations compared with concentrations adjusted for carbon and lipid sources. The $\mathrm{Hg}$ concentrations adjusted for carbon and lipid sources in Bering-Chukchi Sea polar bear liver tissue remained the lowest among subpopulations. Based on these findings, the authors suggest that carbon and lipid sources for polar bears should be taken into account when one is assessing spatial and temporal trends of long-range transported trace elements. Environ. Toxicol. Chem. 2012;31:xxx-xxx. (C) 2012 SETAC
\end{abstract}

Keywords-Polar bear Mercury Trace elements Spatial trends Carbon and lipid sources

\section{INTRODUCTION}

The polar bear (Ursus maritimus) is an apex predator of circumpolar arctic marine ecosystems. Due to its trophic position, the polar bear may be exposed and in some cases have elevated levels of a wide variety of environmental contaminants $[1,2]$. These contaminants include trace elements such as mercury $(\mathrm{Hg})$, but also essential (As, $\mathrm{Cu}, \mathrm{Mn}, \mathrm{Se}$, and $\mathrm{Zn}$ ) and nonessential $(\mathrm{Cd}, \mathrm{Hg}, \mathrm{Pb}$, and $\mathrm{Rb}$ ) elements of both natural and anthropogenic origin, many of which are toxic at elevated concentrations [3]. Mercury and Cd have been detected at high concentrations in species occupying the top of the arctic marine food webs including polar bears [3-6]. Toxicological effects of these trace element contaminants in the Arctic have been of concern in species such as polar bears, seals, beluga whales (Delphinapterus leucas), and bowhead whales (Balaena mysticetus) [7-12]. Of the different chemical forms of $\mathrm{Hg}$, the most important from an environmental toxicology perspective is methylmercury (MeHg). Methylmercury biomagnifies through food chains, and more than $95 \%$ has been shown to be absorbed from the diet in exposed mammals [13]. In recent years, increasingly subtle but important biological effects have been documented, including behavioral, neurochemical, hormonal,

All Supplemental Data may be found in the online version of this article.

* To whom correspondence may be addressed

(robert.letcher@ec.gc.ca).

Published online 15 September 2012 in Wiley Online Library (wileyonlinelibrary.com) and reproductive changes in predatory fish and wildlife exposed to environmentally relevant levels of $\mathrm{MeHg}$ [14].

Trace element concentrations show wide geographical variation among polar bear subpopulations. Studies published over the last 25 years have documented the highest concentrations of total $\mathrm{Hg}$, Se, and As in polar bears from the Beaufort Sea and lowest in southern and western Hudson Bay and the ChukchiBering Sea [3,6,15-17]. In contrast, Cd concentrations in polar bears and ringed seals generally increase from the western to eastern Arctic [3,6,15-18]. Trace element concentrations in arctic biota are influenced by physical factors including riverine output and geology, as well as biological factors such as underlying food web structures that are manifested in the diet of higher trophic level wildlife [18-20]. The relative importance of these underlying factors in modulating geographical differences in trace element concentrations in polar bears and other marine mammals is not completely understood.

The food web length and diet composition of polar bears are known to vary considerably among Arctic subpopulations [21-23]. For example, polar bears feed predominantly on ringed seals (Pusa hispida), but depending on the subpopulation, bearded seals (Erignathus barbatus), harp seals (Phoca groenlandica), harbor seals (Phoca vitulina), hooded seals (Cystophora cristata), walruses (Odobenus rosmarus), narwhals (Monodon monoceros), belugas, bowhead whales, and sperm whales (Physeter macrocephalus) may also form part of their diet $[21,24]$. It is, however, unclear how such trophic factors may influence spatial variation in trace element levels. 
Chemical tracers, such as nitrogen and carbon stable isotope (SI) ratios $\left(\delta^{15} \mathrm{~N}, \delta^{13} \mathrm{C}\right)$ and fatty acid (FA) composition, have been used to elucidate trophic relationships and food web structure [25,26]. For estimating relative trophic positions of animals within a food web, $\delta^{15} \mathrm{~N}$ is frequently used, whereas $\delta^{13} \mathrm{C}$ delineates the major carbon sources of an organism, that is, benthic/pelagic, marine/terrestrial, and freshwater/marine [25]. The FAs may be used to assess the individual diet composition of animals [26]. In addition, transfer of energy from phytoplankton and zooplankton to top predators may be traced using FAs [27], because characteristic FAs synthesized in primary and secondary producers are transferred through food webs [28]. Carbon and nitrogen SIs have become powerful tools to study dietary exposure and biomagnification of persistent contaminants in marine ecosystems [29], whereas FA composition has been used in contaminant studies only recently, including studies of persistent organic pollutant variation among polar bear subpopulations [23,30-32].

We recently reported that concentrations of major bioaccumulative trace elements showed significant variation among subpopulations of polar bears from Alaska to East Greenland [3]. In the present study, we used SI and FA chemical tracers to test the hypothesis that among these same polar bear subpopulations, differences in trace concentrations of essential and nonessential elements are affected by variations in carbon and lipid sources. Before combining the information on trace elements and carbon and lipid sources, we investigated subpopulation differences in carbon and lipid sources assessed using $\delta{ }^{13} \mathrm{C}$ ratio values and fatty acid signatures, respectively.

\section{MATERIALS AND METHODS}

\section{Sample collection and age estimation}

Polar bear liver, muscle, and subcutaneous fat tissues were collected from eight subpopulations in the Canadian Arctic, as well as from the Alaska (Chukchi-Bering Sea) and East
Greenland subpopulations over the years 2005 to 2008 (Fig. 1, Table 1). A vestigial premolar tooth was used to estimate the age of the bears $[33,34]$. Detailed information on sampling and biometric measurements has been comprehensively reported elsewhere [34].

\section{Trace element analysis and quality control}

All trace element analysis of the present polar bear liver samples was carried out at the National Wildlife Research Centre, Environment Canada, Carleton University. Polar bear liver samples were analyzed for $\mathrm{As}, \mathrm{Cd}, \mathrm{Cu}$, total $\mathrm{Hg}, \mathrm{Mn}, \mathrm{Rb}$, $\mathrm{Pb}, \mathrm{Se}$, and $\mathrm{Zn}$. We have thoroughly and recently described [3] the analytical procedures and quality assurance and control used for trace element determination in the liver samples (see Supplemental Data). Briefly, total $\mathrm{Hg}, \mathrm{As}, \mathrm{Cd}, \mathrm{Cu}, \mathrm{Mn}, \mathrm{Pb}, \mathrm{Rb}$, $\mathrm{Se}$, and $\mathrm{Zn}$ were determined in polar bear liver samples using U.S. Environmental Protection Agency method 200.8 with modifications for biological samples. Concentrations of total $\mathrm{Hg}$ were determined by DMA-80 Direct Mercury Analyzer (Milestone), and other elements were determined by ELAN 9000 inductively coupled plasma mass spectrometry from Perkin Elmer. Recoveries of total $\mathrm{Hg}$ for certified reference materials varied between 83 and $111 \%$. Average certified reference material recoveries of other elements ranged from $81 \%$ for $\mathrm{Cu}$ to $104 \%$ for Se. Standard deviations between duplicate results for random liver samples were from 1 to $11 \%$ for $\mathrm{Hg}$, below $10 \%$ for $\mathrm{Cd}, \mathrm{Cu}, \mathrm{Mn}, \mathrm{Rb}, \mathrm{Se}$, and $\mathrm{Zn}$, from 1 to $19 \%$ for As, and from 1 to $14 \%$ for $\mathrm{Pb}$.

\section{Stable isotope and fatty acid analysis}

Carbon source variation of individual polar bears was investigated using $\delta^{13} \mathrm{C}$ ratio values. All carbon SI analyses were carried out by the Environmental Isotope Laboratory, University of Waterloo (Waterloo, ON, Canada). We have described the analytical procedures in comprehensive detail for all bears

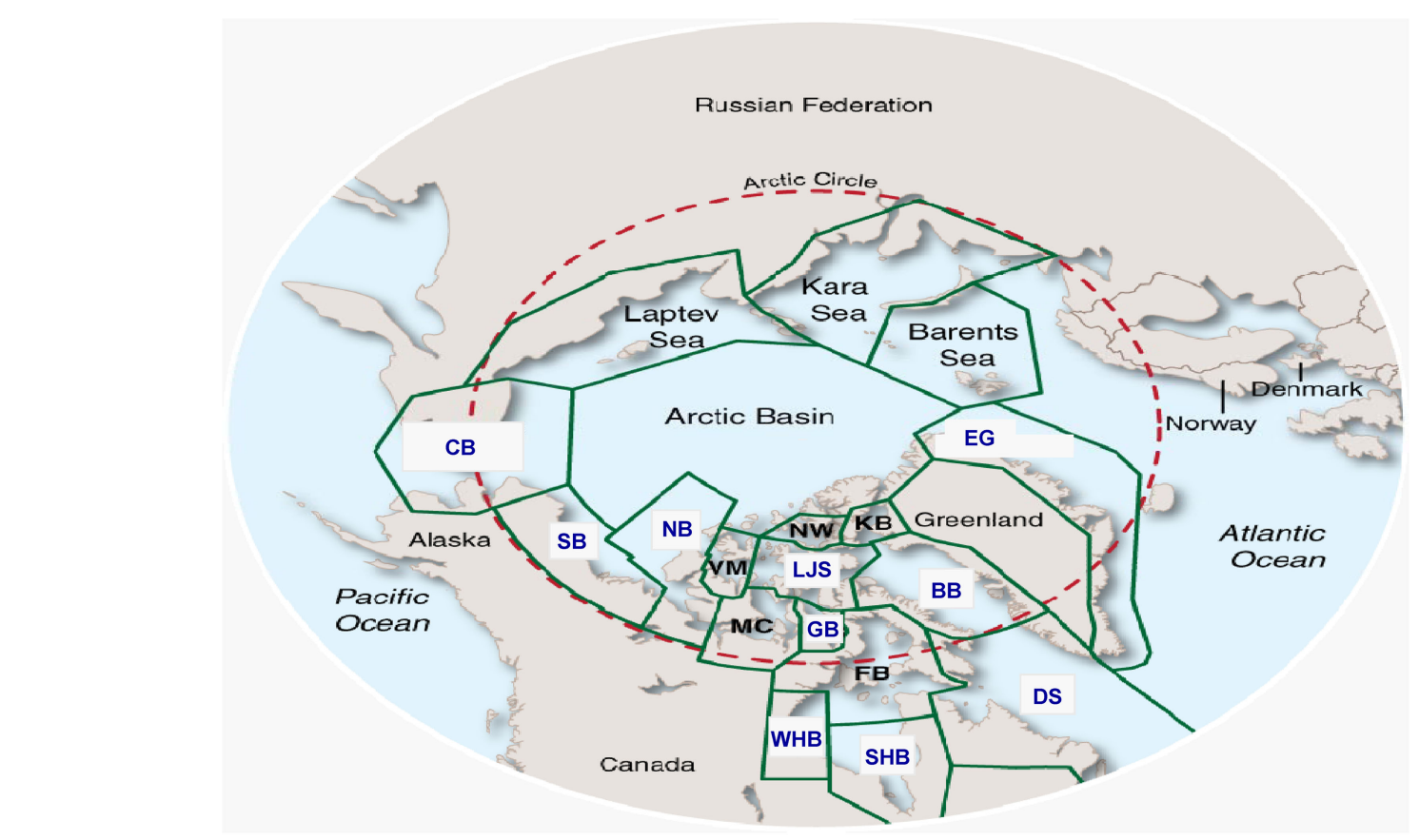

Fig. 1. Polar bear subpopulation ranges throughout the circumpolar basin. Labeled subpopulations denote those examined in the present study: Bering-Chukchi Sea (CB), southern Beaufort Sea (SB), northern Beaufort Sea (NB), Lancaster/Jones Sound (LJS), Gulf of Boothia (GB), western Hudson Bay (WHB), southern Hudson Bay (SHB), Baffin Bay (BB), Davis Strait (DS), and East Greenland (EG). 
Table 1. Subpopulation, number of individuals, age, and stable isotope ratio of carbon ${ }^{\mathrm{a}}$ of polar bears investigated for the influence of dietary tracers, sex, and age on trace element concentrations

\begin{tabular}{|c|c|c|c|}
\hline Subpopulation & No. (males:females) & Median age (range) & $\delta^{13} \mathrm{C} \pm \mathrm{SD}^{\mathrm{a}}$ \\
\hline Alaska, Bering-Chukchi Sea (CB) & $11(7: 4)$ & $7.0(2-22)$ & $-16.8 \pm 0.3$ \\
\hline Southern Beaufort Sea (SB) & $10(7: 3)$ & $9.0(4-20)$ & $-19.1 \pm 0.4$ \\
\hline Northern Beaufort Sea (NB) & $24(17: 7)$ & $6.0(3-24)$ & $-19.2 \pm 0.6$ \\
\hline Gulf of Boothia (GB) & $6(4: 2)$ & $8.5(3-24)$ & $-17.5 \pm 0.5$ \\
\hline Lancaster/Jones Sound (LS) & $12(10: 2)$ & $6.0(3-11)$ & $-17.6 \pm 0.5$ \\
\hline Southern Hudson Bay (SHB) & $12(8: 4)$ & $9.0(3-22)$ & $-18.9 \pm 0.3$ \\
\hline Western Hudson Bay (WHB) & $11(8: 3)$ & $7.0(3-29)$ & $-18.8 \pm 0.6$ \\
\hline Baffin Bay, N.E. Baffin Island (BB) & $10(7: 3)$ & $5.0(2-10)$ & $-17.5 \pm 0.6$ \\
\hline Davis Strait, S.E. Baffin Island (DS) & $5(5: 0)$ & $4.0(3-6)$ & $-16.6 \pm 0.7$ \\
\hline E. Greenland, Scoresbysund (EG) & $20(14: 6)$ & $6.5(3-19)$ & $-18.7 \pm 0.3$ \\
\hline All females & 34 & $7(2-24)$ & $-18.6 \pm 1.0$ \\
\hline All males & 87 & $7(3-29)$ & $-18.2 \pm 1.0$ \\
\hline
\end{tabular}

${ }^{\text {a }}$ McKinney et al. [23].

in the present study [23]. For SI analysis, polar bear muscle tissues were homogenized and lipids were removed and prepared for analysis by standard protocols (e.g., Hebert et al. [35]). Carbon SIs were determined with an elemental analyzer coupled to a continuous flow isotope ratio mass spectrometer. The SI results were generally corrected using carbon standards International Atomic Energy Agency-CH6 (sugar), Environmental Isotope Laboratory-72 (cellulose), and Environmental Isotope Laboratory-32 (graphite). The error for clean ballmilled standard material was $\pm 0.2 \%$. Mean deviation of duplicate SI analysis on $10 \%$ of the polar bear samples was $0.07 \%$. Carbon compositions were calculated based on Carlo Erba Elemental Standards B2005, B2035, and B2036 with an error of $\pm 1 \%$. See Supplemental Data for more detail.

All FA analyses for the polar bear subcutaneous fat tissue and quality control samples were carried out by the Organic Contaminants Research Laboratory at the National Wildlife Research Centre and are described elsewhere [23,30] (see Supplemental Data). Extraction and analysis of FAs was from 10 to $20 \mathrm{mg}$ of inner adipose tissue of a collected polar bear sample. The 5- $\alpha$-cholestane was used as internal standard. Extracted FAs were methylated via the Hilditch reagent to fatty acid methyl esters (FAMEs). The FAMEs were determined by gas chromatography-flame ionization detection, with quantification against a Supelco, 37-component FAME external standard. Here, we report only on the dietary FAs, that is, those that are incorporated relatively unchanged from prey to monogastric predator adipose tissues [26] that were available for quantification based on the external standard. Each FAME was calculated as the mass percentage of total dietary FAME. The 12 FAs used in the present study included linoleic acid (18:2n-6), $\gamma$-linolenic acid (18:3n-6), cis-11-eicosenoic acid (20:1n-9), $\alpha$-linolenic acid (ALA; 18:3n-3), cis-11,14-eicosadienoic acid (20:2n-6), cis-8,11,14-eicosatrienoic acid (20:3n-6), erucic acid (22:1n-9), cis-11,14,17-eicosatrienoic acid (ETA; 20:3n-3), arachidonic acid (ARA; 20:4n-6), cis-5,8,11,14,17eicosapentaenoic acid (EPA; 20:5n-3), cis-7,10,13,16,19-docasapentaenoic acid (DPA; 22:5n-3), and cis-4,7,10,13,16,19docasahexaenoic acid (DHA; 22:6n-3).

A blank, duplicate, and two reference materials, Great Lakes herring gull (Larus argentatus) egg pool and the National Institute of Standards and Technology pilot whale blubber standard reference material 1945 , were extracted with every batch of 20 FA samples. Relative differences in duplicate analyses of samples were on average 6 and 7\%, respectively. The relative standard deviation of dietary FAs averaged $6 \%$ for the herring gull egg pool. The SRM1945 dietary FA values were on average within $15 \%$ relative standard deviation of our laboratory results from the 2007 National Institute of Standards and Technology/National Oceanic and Atmospheric Administration Interlaboratory Comparison Exercise Program for Organic Contaminants in Marine Mammal Tissues. Recovery of 5 - $\alpha$-chlolestane was $100 \pm 10 \%$. See Supplemental Data for more details.

\section{Data analysis}

Statistical analysis were carried out using R Version 2.11.1 [36]. To investigate subpopulation differences in lipid sources, FA composition was explored by correspondence analysis run on the 12 FAs [37]. The FA indexes $\left(\mathrm{FA}_{\text {ind }} 1\right.$ and $\left.\mathrm{FA}_{\text {ind }} 2\right)$ were generated for further analysis from the first and second axis of a correspondence analysis run on the 12 FAs. Sample scores were plotted by subpopulation, sex, and season. Season refers to autumn (October-November), winter (December-March), and spring (April-May). Variation of carbon source using $\delta^{13} \mathrm{C}$ as a tracer, among polar bear subpopulations, was tested by an analysis of variance. To explore whether the differences in trace concentrations of essential and nonessential elements are affected by variation in carbon and lipid sources, we visualized the relationships between chemical tracers and trace element concentrations using the multivariate redundancy analysis (RDA) [38]. The analysis was made on $\mathrm{R}$ package ade 4 and based on the covariance matrix of centered log-transformed trace element concentrations. Prior to analysis, the explanatory measures of lipid and carbon source variation $\left(\mathrm{FA}_{\text {ind }} 1, \mathrm{FA}_{\text {ind }} 2\right.$, $\delta^{13} \mathrm{C}$ ) were standardized. Age was also added as an explanatory variable because preliminary analysis revealed significant relationships between age and trace element concentrations. Because $\mathrm{Pb}$ was detected at concentrations close to the minimum detection limit in $45 \%$ of the samples, it was excluded from the final RDA to avoid variables associated with high uncertainty dominating the ordination. The RDA model was highly significant based on the Monte-Carlo permutation test (1,000 replicates, RV coefficient $0.18, p=0.001)$. Sample scores were plotted by subpopulation, sex, and season. Correlations based on ln-transformed data are shown in the text as Pearson correlation coefficients $(r)$ with $95 \%$ confidence intervals.

We used linear models (multiple regressions) to quantify the relationships between trace element concentrations and carbon and lipid sources. In detail, we investigated the effect of SI and FA values on the concentrations of individual trace elements, 
which were related to chemical tracers according to the RDA. We selected the most parsimonious linear models explaining the variance of trace element concentrations using likelihood ratio tests. Full models, including lipid and carbon source descriptors $\left(\delta^{13} \mathrm{C}\right.$ and $\left.\mathrm{FA}_{\text {ind }} 1, \mathrm{FA}_{\text {ind }} 2\right)$, sex, and age as explanatory variables, were simplified by eliminating interaction terms and variables if their removal did not result in a significant increase in deviance. Throughout the analysis, diagnostic plots of residuals were used to verify that the linear model assumptions were met, that is, most importantly, constant variance between residuals. The trace element concentrations were $1 n-$ transformed to meet model assumptions. The analytical diagnostics revealed one outlier in the model for As concentrations, and removal of the outlier did not affect the significance of the results. Parameter estimates $(\beta)$ with $95 \%$ confidence intervals are given in the text.

Furthermore, we investigated whether polar bear subpopulation differences in trace element concentrations are affected by variation in the carbon and lipid sources. We adjusted the trace element concentrations for the lipid and carbon source descriptors and other variables (sex and age), if these were included in the most parsimonious models (Table 2). We then compared the adjusted element levels with those we reported previously for the unadjusted levels in the same individuals [3]. We tested the effect of carbon and lipid source variation on pairwise differences between subpopulations by running a post hoc Tukey's honestly significant difference test after and before adjusting the trace element concentrations for carbon and lipid source descriptors. After adjusting for carbon and lipid source descriptors, this means that the trace element concentrations were adjusted according to all the variables included in the most parsimonious models (Table 2). Before adjusting for carbon and lipid source descriptors, this means that the trace element concentrations were adjusted only to other variables (age and sex) if these were included in the most parsimonious models (Table 2). Level of significance was set to $\alpha \leq 0.05$.

\section{RESULTS AND DISCUSSION}

\section{Regional variation in carbon and lipid sources}

The $\delta^{13} \mathrm{C}$ signatures were depleted in the northern and southern Beaufort Sea, Hudson Bay, and East Greenland subpopulations compared with the remaining subpopulations (analysis of variance, $F_{9,111}=40, p<0.001$, Table 1). The $\delta{ }^{13} \mathrm{C}$ values are enriched going from terrestrial/freshwater organic matter to pelagic phytoplankton to ice algae and benthos [25]. The depleted $\delta^{13} \mathrm{C}$ signatures in the polar bears from the Beaufort Sea and Hudson Bay may originate from input of terrestrial organic carbon by rivers including the Mackenzie River, running into the Beaufort Sea, and several rivers feeding the Hudson Bay basin $[39,40]$. Although Hudson Bay polar bears spend prolonged seasonal periods on land,

Table 2. Explanatory variables including degrees of freedom $(d f)$ and $r^{2}$ for the most parsimonious linear models for $\log _{\mathrm{e}}$-transformed trace element concentrations

\begin{tabular}{lcccccc}
\hline & $\delta^{13} \mathrm{C}$ & $\mathrm{FA}_{\text {ind }} 1$ & $\mathrm{FA}_{\text {ind }} 2$ & Age & $d f$ & $r^{2}$ \\
\hline $\log (\mathrm{As})$ & $\mathrm{X}$ & $\mathrm{X}$ & $\mathrm{X}$ & & 3,115 & 0.29 \\
$\log (\mathrm{Cd})$ & & $\mathrm{X}$ & $\mathrm{X}$ & & 1,118 & 0.09 \\
$\log (\mathrm{Hg})$ & $\mathrm{X}$ & $\mathrm{X}$ & 4,115 & 0.31 \\
$\log (\mathrm{Se})$ & $\mathrm{X}$ & $\mathrm{X}$ & $\mathrm{X}$ & $\mathrm{X}$ & 4,115 & 0.28 \\
\hline
\end{tabular}

$\mathrm{FA}_{\text {ind }}=$ fatty acid index. incorporation of terrestrial-based carbon from feeding on berries has been suggested to be a minor part of their carbon bulk [41]. The depleted $\delta^{13} \mathrm{C}$ values in East Greenland polar bears may be related to the phenomenon that freshwater from the Arctic Ocean originating mainly from Russian and Canadian river runoff is strongly confined nearly to the East Greenland coast, as most of the polar sea ice is transported southward along the East Greenland shores, where it melts as it meets with warmer ocean currents [42].

Major FAs included 20:1n-9, 20:5n-3, 22:5n-3, 22:6n-3, and 18:2n-6 as presented in detail by McKinney et al. [23]. These FAs originate from pelagic herbivorous plankton and phytoplankton such as Calanus copepods, diatoms, dinoflagellates, and Phaeosystis pouchetii [28]. The FA composition in polar bears thus suggests that polar bear diet is coupled mainly to the pelagic marine food web, which is in agreement with previous carbon SI estimations reported by Hobson et al. [43]. The first axis explaining $64 \%$ of the FA variation distinguished mostly between 20:1n-9 and 22:1n-9, and 20:5n-3 (Fig. 2A). Correspondence analysis indicated that FA composition differed among the polar bear subpopulations, whereas the variation between seasons and sexes was minor (Fig. 2B-D). This is similar to previous results reported by McKinney et al. [23]. The first axis separated Hudson Bay and Chukchi Sea polar bears mainly from the other subpopulations, and showed a strong correlation with latitude. The bears from lower latitude Hudson Bay and Chukchi Sea populations had lower proportions of 20:1n-9 and 22:1n-9 compared with the polar bears from higher latitudes. The FAs 20:1n-9 and 22:1n-9 are biosynthesized by Calanus copepods and used as specific markers for this taxon [28], which is the major zooplankton taxa in the high Arctic $[44,45]$. Our results suggest that Calanus copepods are proportionally greater in the polar bear food webs in higher latitudes compared with those from lower latitudes. This is in accordance with differences reported elsewhere in zooplankton composition among Hudson Bay, Chukchi Sea, and the remaining areas [44-47].

\section{Relationships between carbon and lipid sources and trace elements}

Concentrations of $\mathrm{Hg}$, Se, As, and $\mathrm{Cd}$ were related to $\mathrm{FAs}$, $\delta{ }^{13} \mathrm{C}$, or both based on the ordination plot derived from the RDA (Fig. 3A). Plotting sample scores revealed that the relationships between trace elements were mainly related to subpopulation differences (Fig. 3B), whereas sex and season had minor influence on these relationships (Fig. 3C,D).

$\mathrm{Hg}$ concentrations were negatively related to $\delta^{13} \mathrm{C}$ (Fig. 3A; $\beta=-0.27[-0.45,-0.09])$, which is in accordance with a previous report on $\mathrm{Hg}$ in polar bears from western Hudson Bay and southern Beaufort Sea [22]. As mentioned earlier, depleted $\delta^{13} \mathrm{C}$ signatures may originate from terrestrial organic carbon transported by rivers. Riverine transport is also a major source of $\mathrm{Hg}$ to the Arctic Ocean [48]. Thus, polar bear food webs rich in river-exported carbon may lead to elevated total $\mathrm{Hg}$ concentrations in polar bears. Concentrations of total $\mathrm{Hg}$ also showed a positive relationship with $\mathrm{FA}_{\text {ind }} 1$ (Fig. $3 \mathrm{~A} ; \beta=1.5$ $[0.9,2])$, which was positively loaded with the Calanus FA marker 20:1n-9 (Fig. 2A). This raises the question of whether food webs rich in Calanus accumulate more $\mathrm{Hg}$ compared with food webs deficient in Calanus. Previous studies on beluga whales found positive correlations between total $\mathrm{Hg}$ concentrations in liver and muscle and long chain monounsaturated fatty acids (20:1n-7, 20:1n-9, 22:1n-9, and 22:1n-11) [32], which are biosynthesized in Calanus-copepods [28]. To our 


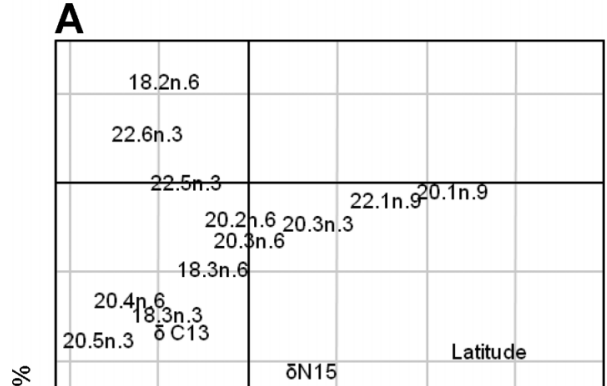

B
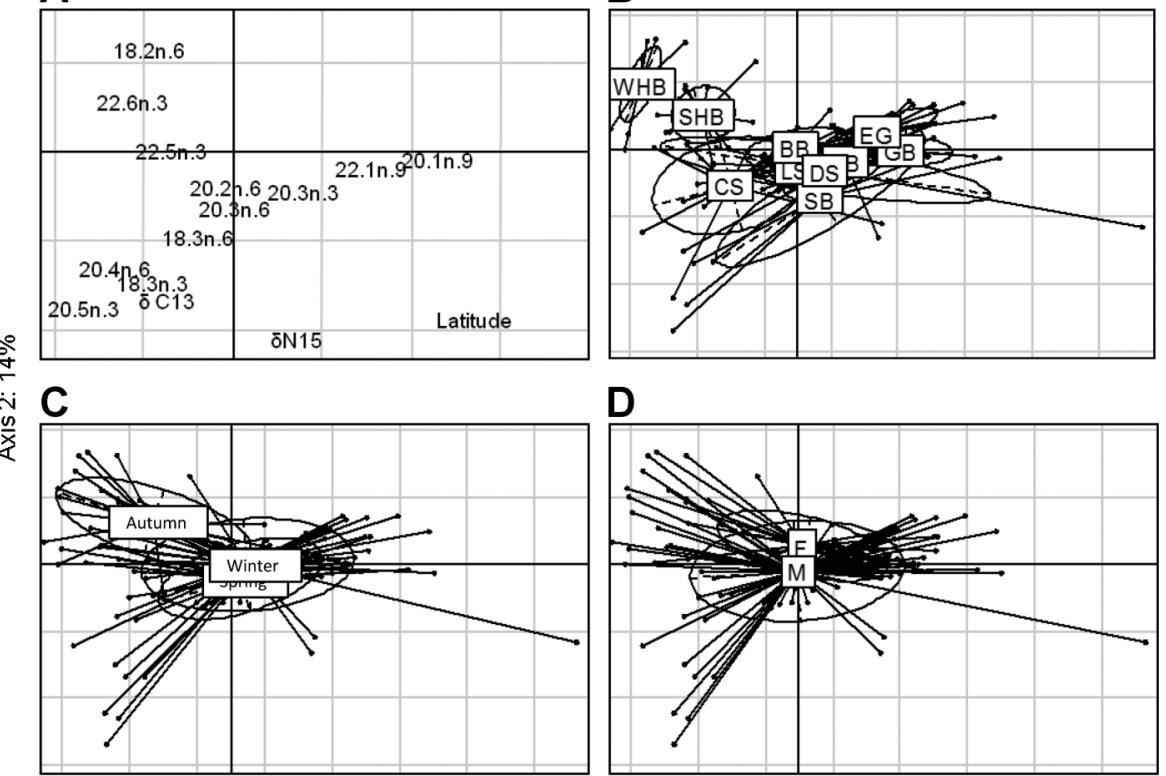

D

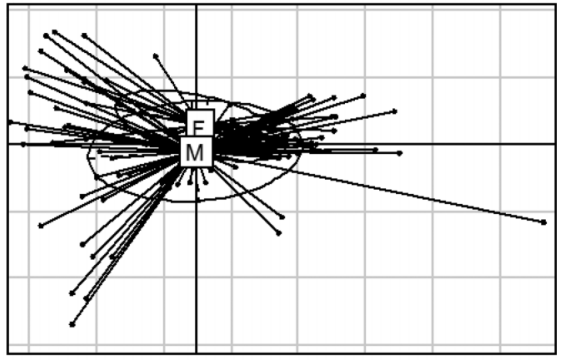

Axis 1: $64 \%$

Fig. 2. Ordination plots from correspondence analysis based on mass percentage of total dietary fatty acids (FAs) in polar bear subpopulations (A). Sample scores are grouped by subpopulation $(\mathbf{B})$, season $(\mathbf{C})$, and $\operatorname{sex}(\mathbf{D})$. The first and second axes explained 64 and $14 \%$ of the total variation, respectively. Latitude and $\delta^{13} \mathrm{C}$ are shown as supplementary variables. See Figure 1 for abbreviation definitions.

A

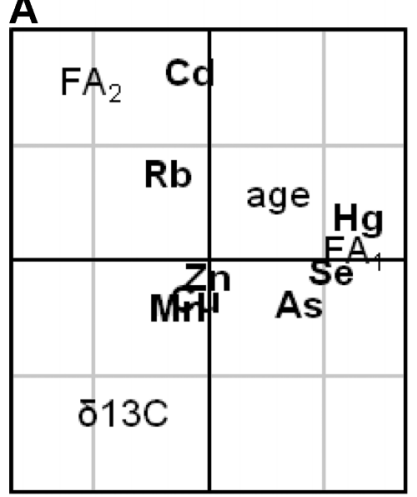

B

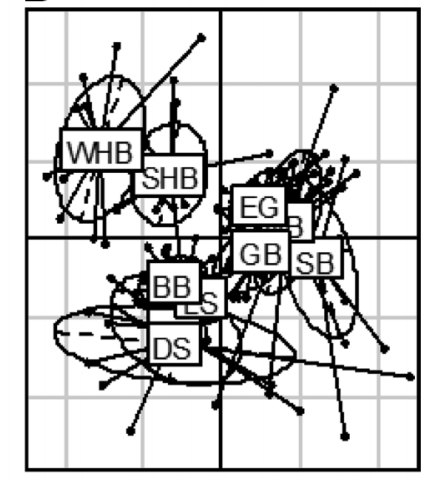

C

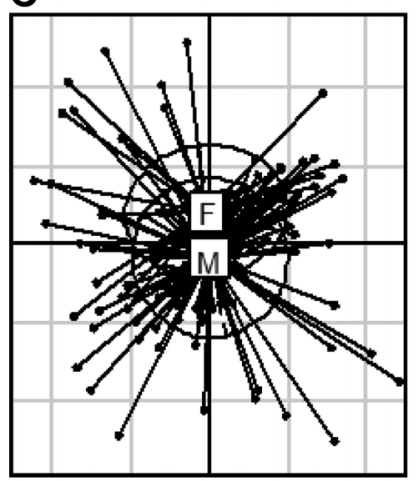

D

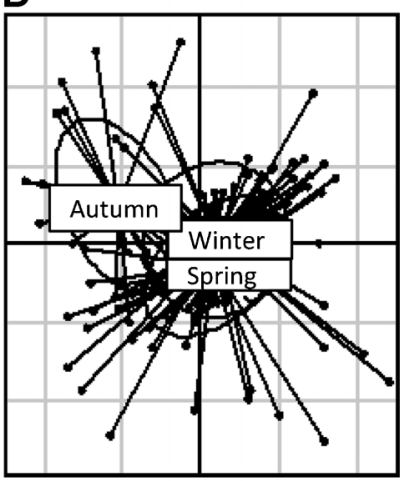

Fig. 3. Ordination plots from redundancy analysis (RDA) based on covariance matrix of log-transformed trace element concentrations in the liver of polar bears. The relationships are shown between response variables (trace element concentrations) and explanatory variables (chemical tracers and age) (A). The sample scores are grouped by subpopulation (B), sex (C), and season (D). The first linear combination of the explanatory variables explained $33 \%$ of the response variables and the second, $16 \%$. The first axis explained $89 \%$ of the variation and second axis, $8.7 \%$. See Figure 1 for abbreviation definitions.

knowledge, there is no comparative literature about $\mathrm{Hg}$ uptake by Calanus compared with the major zooplankton taxa from the subarctic. Calanus may be exposed to relatively high $\mathrm{Hg}$ levels due to its foraging ecology. The key Calanus-copepod in Arctic shelf seas, $C$. glacialis, times its foraging to the ice algal bloom in April, whereas their offspring feeds on the phytoplankton bloom following the sea-ice break-up [49]. Interestingly, $\mathrm{Hg}$ concentrations in sea-ice brines are highest in April and decrease with the progressing melting season when melt water flushes the brine into the underlying seawater [50]. Concentrations of $\mathrm{Hg}$ were positively related to age $(\beta=0.0478$ [0.016, 0.080], which is in accordance with previous studies on polar bears $[4,17]$.

Strong positive correlations of Se and As were found with total $\mathrm{Hg}(r=0.97[0.95,0.98]$ and 0.80 [0.72, 0.85], respectively), which were thus positively related to $\mathrm{FA}_{\text {ind }} 1$ and negatively to $\delta^{13} \mathrm{C}$. Concentrations of Se were also positively related to age. Strong correlations between $\mathrm{Hg}$ and Se have been reported by numerous wildlife studies, which are probably related to a detoxifying effect of Se on $\mathrm{Hg}$ [12]. Mercury forms the equimolar inert tiaminite Se complex Hg:Se [51], and the molar ratio of $\mathrm{Hg}$ :Se varied between 0.8 to 1.6 in the present polar bears, which is at a similar range as previously observed in polar bears [6,52]. The underlying reason for the positive correlation of As with either $\mathrm{Hg}$ or $\mathrm{Se}$ is not clear. First, biomagnification potency of As has not been demonstrated in contrast to $\mathrm{Hg}$ [53-56]. Second, although arsenite $\left(\mathrm{As}^{3+}\right)$ and $\mathrm{Se}$ may interact by forming an equimolar complex with glutathione [51], the major As form in marine mammals (seals) and birds is arsenobetaine [57], which to our knowledge is not known to interact with Se. However, different forms of As have not been investigated in polar bears, and further research is warranted to investigate the underlying reason for strong correlations of As with $\mathrm{Hg}$ and $\mathrm{Se}$.

Concentrations of $\mathrm{Cd}$ were positively related to $\mathrm{FA}_{\text {ind }} 2$ (Fig. 3A; $\beta=1.5[0.6,2.3]$ ), which loaded negatively with 
FA 20:4n-6 (Fig. 2A). This suggests enrichment of Cd from near-shore to the pelagic environment, because $20: 4 n-6$ is synthesized in macro-algae growing in shallow waters $(<12 \mathrm{~m})$ [58]. This is in agreement with increasing Cd levels from the inner fjord system toward the open sea in, for example, the Greenland environment [59]. In the case of $\mathrm{Cu}, \mathrm{Mn}, \mathrm{Rb}$, and $\mathrm{Zn}$, these were not related to carbon or lipid source descriptors (Fig. 3A). Thus, $\mathrm{Cu}, \mathrm{Mn}$, and $\mathrm{Zn}$ are all essential elements, and their uptake is naturally regulated by organisms, whereas the role of $\mathrm{Rb}$ as a micronutrient has been discussed [60].

\section{Influence of carbon and lipid sources on subpopulation differences} in trace element concentrations

When adjusted for carbon and lipid sources as measured by $\delta^{13} \mathrm{C}$ and $\mathrm{FA}$ tracers, total $\mathrm{Hg}$ concentrations were significantly different from concentrations that were not adjusted (Fig. 4). Mean total $\mathrm{Hg}$ concentrations were higher in southern and western Hudson Bay polar bears and lower in southern and northern Beaufort Sea subpopulations when adjusted for $\delta{ }^{13} \mathrm{C}$ and FA tracers compared with unadjusted concentrations. We recently reported that total $\mathrm{Hg}$ concentrations in polar bears from northern and southern Beaufort Sea were higher than in any other subpopulations except Lancaster/Jones Sound and the Gulf of Boothia, whereas total Hg concentrations were lower in southern and western Hudson Bay polar bears compared with any other subpopulation except those of the Davis Strait and Chukchi Sea [3]. The subpopulation differences of concentrations of total $\mathrm{Hg}$ adjusted for carbon and lipid sources were less pronounced than unadjusted trends among these subpopulations. Adjusted total $\mathrm{Hg}$ concentrations in southern and northern Beaufort Sea polar bears were generally not higher compared with other subpopulations $(0.12<p<1 ; p=0.06$ for northern Beaufort Sea-East Greenland; southern Beaufort Sea-southern Hudson Bay, $p=0.001)$, except for Chukchi Sea $(p<0.001)$. Total $\mathrm{Hg}$ concentrations adjusted for carbon and lipid sources in polar bears from western Hudson Bay were similar to all the subpopulations $(0.15<p<1)$ and higher than in Chukchi Sea polar bears $(p=0.042)$. Adjusted total $\mathrm{Hg}$ concentrations for the southern Hudson Bay subpopulation were still lower compared with polar bears from northern Beaufort Sea and Lancaster/Jones Sound ( $p \geq 0.001)$. Because Se and total $\mathrm{Hg}$ concentrations were strongly correlated, concentrations of Se adjusted for carbon and lipid sources were less pronounced compared with unadjusted trends among these subpopulations (Fig. 4). Concentrations of As adjusted for carbon and lipid sources were, in general, similar between subpopulations ( $p>0.095$; East Greenland-northern Beaufort Sea $p=0.024)$. However, subpopulation differences were observed in the unadjusted As concentrations [3] (Fig. 4). Prior to adjustments for lipid source, concentrations of $\mathrm{Cd}$ in polar bears generally increased from east to west [3]. However, after adjustments, this trend was less pronounced (Fig. 4).

Our results suggest that differences in $\mathrm{Hg}, \mathrm{Se}, \mathrm{As}$, and $\mathrm{Cd}$ concentrations among polar bear subpopulations are partly explained by variation in carbon and lipid sources. Low concentrations of total $\mathrm{Hg}$ adjusted for carbon and lipid sources in Chukchi Sea polar bears may be related to $\mathrm{Hg}$ concentrations in water. Dissolved gaseous $\mathrm{Hg}$ in surface waters from the Chukchi-Bering Sea has also been reported to be low compared with the remaining Arctic [61]. The Chukchi-Bering Sea is influenced by inflow of water from the Pacific Ocean, where evasion of gaseous mercury is not blocked by ice cover [62].

\section{Confounding factors - methylated Hg species in water column and food web length}

A recent study comparing total $\mathrm{Hg}$ levels in the hair of polar bears from western Hudson Bay and the southern Beaufort Sea concluded that the differences in total $\mathrm{Hg}$ levels between these two subpopulations may be related to both the length of the food web and pelagic concentrations of $\mathrm{MeHg}$ concentrations [22]. Concentrations of $\mathrm{MeHg}$ in the water column vary between the Canadian Arctic archipelago and Hudson Bay, whereas total $\mathrm{Hg}$ concentrations are similar in the different areas within the Canadian Arctic and sub-Arctic [22,63]. Monomethylated Hg
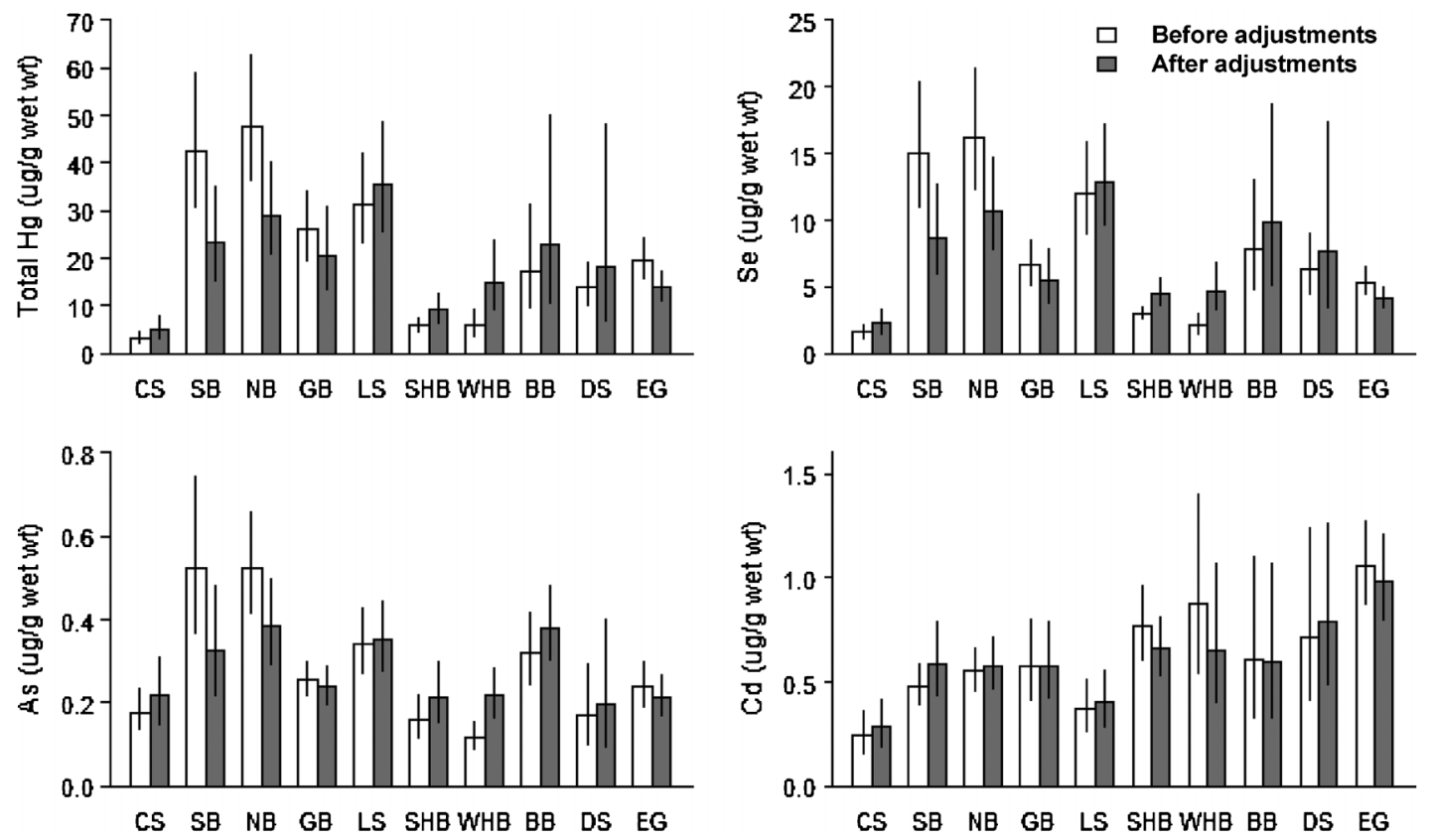

Fig. 4. Geometric mean concentrations ( $\mu \mathrm{g} / \mathrm{g}$ wet wt $\pm 95 \%$ confidence intervals) of total $\mathrm{Hg}$, Se, As, and Cd in liver of polar bears from 10 subpopulations before [3] and after adjusting for lipid and carbon sources (see Table 2 for details). See Figure 1 for abbreviation definitions. 
is the toxic form of $\mathrm{Hg}$ accumulating in the food web, whereas elemental $\mathrm{Hg}$ has poor bioaccumulation potential [64]. Although our results suggest that total $\mathrm{Hg}$ variation among polar bear subpopulations is mainly explained by food web differences, the results for the Canadian subpopulations may be partly confounded by regional variation in $\mathrm{MeHg}$ species in the water column $[22,63]$. We had reported that the highest concentrations of total $\mathrm{Hg}$ (corrected for sex and age) were in polar bears from the Beaufort Sea, Lancaster Sound, and Gulf of Boothia, followed by the Baffin Bay and Davis Strait; Hudson Bay bears had the lowest $\mathrm{Hg}$ concentrations [3]. Similarly, concentrations of $\mathrm{MeHg}$ in mid-depth and deep water column were reported to be highest in the southern Beaufort Sea and Lancaster Sound and lower for Davis Strait to Hudson Bay $[22,63]$. However, the geographical differences in $\mathrm{MeHg}$ concentrations in the water column were smaller compared with differences that we observed among the polar bear subpopulations. Furthermore, the Beaufort Sea and Baffin Bay were shown not to have different $\mathrm{MeHg}$ concentrations in the water column [22,63] as they did for total $\mathrm{Hg}$ concentrations in polar bears. Therefore, the difference that we presently observed in total $\mathrm{Hg}$ concentrations between Beaufort Sea and Baffin Bay subpopulations could be explained by differences in carbon and lipid sources between the Beaufort Sea and Baffin Bay.

Trophic biomagnification of $\mathrm{Hg}$ has been reported in both polar bears $[22,65]$ and marine food webs $[56,66]$. We previously reported that $\delta^{15} \mathrm{~N}$ values varied among the polar bear subpopulations [23]. As part of the present study, we found that the $\delta^{15} \mathrm{~N}$ values were positively correlated with the concentrations of total $\mathrm{Hg}$, Se, and As (Supplemental Data, Fig. S1). This finding suggests that regional differences in polar bear food web length play a role in explaining subpopulation differences in trace element concentrations. However, the trophic baseline of $\delta^{15} \mathrm{~N}$ values in Arctic marine food webs may vary significantly between geographical regions $[67,68]$. Thus, the differences in $\delta^{15} \mathrm{~N}$ values among polar bear subpopulations do not necessary reflect their trophic position in the food web. We recommend that future studies should investigate the role of the whole food web length in subpopulation variation of trace element concentrations in polar bears. This will require a thorough investigation of $\delta^{15} \mathrm{~N}$ values at lower trophic levels to properly adjust polar $\delta^{15} \mathrm{~N}$ values to possible variations in $\delta^{15} \mathrm{~N}$ baseline.

\section{CONCLUSIONS}

The present study demonstrates the importance of including information on carbon and lipid sources when interpreting the spatial trends of certain trace elements in polar bears. Subpopulation differences are partly explained by variation in carbon and lipid sources, but $\mathrm{MeHg}$ in the water column and food web length may also play an important role in total $\mathrm{Hg}$ concentrations in apex predators. It has been proposed that trace element concentrations in arctic apex predators may change during the next decades, as $\mathrm{Hg}$ and $\mathrm{Cd}$ emissions are expected to increase due to the increasing use of coal in Asia and worldwide $[69,70]$. Additionally, changing climate may be affecting the natural cycles and long-range transport of these elements $[62,71]$, as well as access, abundance, and distribution of polar bear prey. Frequent monitoring of both polar bear food web structure and exposure to trace elements is thus important to detect possible and rapid changes.

\section{SUPPLEMENTAL DATA}

In the Supplemental Information section, comprehensive details are given on methods for stable isotopes, fatty acids, and total $\mathrm{Hg}$ and other elements under study. Supplemental Figure $\mathrm{S} 1$ shows the relationships between liver total $\mathrm{Hg}$, Se, and As, and muscle stable nitrogen isotope $\left(\delta^{15} \mathrm{~N}\right)$ values in polar bears from the 10 subpopulations. (37 KB DOC).

Acknowledgement-For Canadian sampling and assistance, we thank polar bear hunters, Nunavut Hunters and Trappers Organizations, Nunavut Department of Environment conservation officers and lab technicians (A. Coxon), and Environment Canada's National Wildlife Specimen Bank at the National Wildlife Research Centre. We thank Ewa Neubauger and France Maisonneuve in the Lab Services section at the National Wildlife Research Centre for element analysis of the samples. Thanks to the Alaska Native hunters who took the extra time to collect and send the polar bear samples, the U.S. Fish and Wildlife Service for processing the shipment to the National Institute of Standards and Technology, and R. Pugh (Hollings Marine Laboratory, National Institute of Standards and Technology) for assistance with the Chukchi-Bering Sea samples. For East Greenland sampling and assistance, we thank local hunters, J. Brønlund, M. Kirkegaard, S. Joensen, and L. Bruun. We thank S. Falk-Petersen, M. Granskog, J. Søreide, and A. Wold for discussions on data interpretation. This study was funded by the Northern Contaminants Program (Department of Indian and Northern Affairs Canada) (R.J.L.) and the Molson Foundation (R.J.L.). Greenland program funding was from the International Polar Year program BearHealth, the Kommissionen for Videnskabelige Unders øgelsa i Grønland, DANCEA, and the Prince Albert II Foundation. The U.S. Fish and Wildlife Service, Marine Mammals Management, contributed to Alaskan funding.

\section{REFERENCES}

1. Letcher RJ, Bustnes JO, Dietz R, Jenssen BM, Jorgensen EH, Sonne C, Verreault J, Vijayan MM, Gabrielsen GW. 2010. Exposure and effects assessment of persistent organohalogen contaminants in arctic wildlife and fish. Sci Total Environ 408:2995-3043.

2. Riget F, Braune B, Bignert A, Wilson S, Aars J, Born E, Dam M, Dietz R, Evans M, Evans T, Gamberg M, Gantner N, Green N, Gunnlaugsdottir H, Kannan K, Letcher R, Muir D, Roach P, Sonne C, Stern G, Wiig Ø. 2011. Temporal trends of $\mathrm{Hg}$ in Arctic biota, an update. Sci Total Environ 409:3520-3526.

3. Routti H, Letcher R, Born EW, Branigan M, Dietz R, Evans TJ, Fisk AT, Peacock E, Sonne C. 2011. Spatio-temporal trends of selected trace elements in liver tissue from polar bears (Ursus maritimus) from Alaska, Canada and Greenland. J Environ Monit 13:2260-2267.

4. Dietz R, Riget F, Johansen P. 1996. Lead, cadmium, mercury and selenium in Greenland marine animals. Sci Total Environ 186:67-93.

5. Muir D, Braune B, DeMarch B, Norstrom R, Wagemann R, Lockhart L, Hargrave B, Bright D, Addison R, Payne J, Reimer K. 1999. Spatial and temporal trends and effects of contaminants in the Canadian Arctic marine ecosystem: A review. Sci Total Environ 230:83-144.

6. Dietz R, Riget F, Born EW. 2000. Geographical differences of zinc, cadmium, mercury and selenium in polar bears (Ursus maritimus) from Greenland. Sci Total Environ 245:25-47.

7. Rosa C, Blake JE, Bratton GR, Dehn LA, Gray MJ, O'Hara TM. 2008. Heavy metal and mineral concentrations and their relationship to histopathological findings in the bowhead whale (Balaena mysticetus). Sci Total Environ 399:165-178.

8. Basu N, Scheuhammer AM, Sonne C, Letcher RJ, Born EW, Dietz R. 2009. Is dietary mercury of neurotoxicological concern to wild polar bears (Ursus maritimus)? Environ Toxicol Chem 28:133-140.

9. Sonne C, Dietz R, Leifsson PS, Asmund G, Born EW, Kirkegaard M. 2007. Are liver and renal lesions in East Greenland polar bears (Ursus maritimus) associated with high mercury levels? Environ Health 6:11.

10. Sonne-Hansen C, Dietz R, Leifsson PS, Hyldstrup L, Riget FF. 2002. Cadmium toxicity to ringed seals (Phoca hispida): An epidemiological study of possible cadmium-induced nephropathy and osteodystrophy in ringed seals (Phoca hispida) from Qaanaaq in Northwest Greenland. Sci Total Environ 295:167-181.

11. Woshner VM, O'Hara TM, Eurell JA, Wallig MA, Bratton GR, Suydam RS, Beasley VR. 2002. Distribution of inorganic mercury in liver and kidney of beluga and bowhead whales through autometallographic development of light microscopic tissue sections. Toxicol Pathol 30: 209-215. 
12. Dietz R, Basu N, Braune B, O’Hara T, Scheuhammer T, Sonne C. 2011 What are the toxicological effects of mercury in Arctic Biota? In Outridge P, Dietz R, eds, AMAP Assessment 2011: Mercury in the Arctic. Arctic Monitoring and Assessment Programme (AMAP), Oslo, Norway, pp 113-130.

13. Berlin M. 1986. Mercury. In Friberg L, Nordberg GF, Vouk VB, eds, Handbook on the Toxicology of Metals. Elsevier Science Publishers, New York, NY, USA, pp 187-445.

14. Scheuhammer AM, Basu N, Evers DC, Heinz GH, Sandheinrich M, Bank MS. 2011. Toxicology of mercury in fish and wildlife: Recent advances. In Bank MS, ed, Mercury in the Environment: Pattern and Process. University of California Press, Berkley, CA, USA.

15. Norstrom RJ, Schweinsberg RE, Collins BT. 1986. Heavy metals and essential elements in livers of the polar bear (Ursus maritimus) in the Canadian Arctic. Sci Total Environ 48:195-212.

16. Braune BM, Norstrom RJ, Wong MP, Collins BT, Lee J. 1991 Geographical-distribution of metals in livers of polar bears from the Northwest-Territories, Canada. Sci Total Environ 100:283-299.

17. Rush SA, Borgå K, Dietz R, Born EW, Sonne C, Evans T, Muir DCG, Letcher RJ, Norstrom RJ, Fisk AT. 2008. Geographic distribution of selected elements in the livers of polar bears from Greenland, Canada and the United States. Environ Pollut 153:618-626.

18. Wagemann R, Innes S, Richard PR. 1996. Overview and regional and temporal differences of heavy metals in Arctic whales and ringed seals in the Canadian Arctic. Sci Total Environ 186:41-66.

19. Douglas T, Amyot M, Barkay T, Berg T, Chételat C, Constant P, Dommergue A, Evans M, Ferrari C, Gantner K, Johnson M, Kirk J, Kroer N, Larose C, Lean D, Loseto L, Macdonald R, Muir D, Gissel Nielsen T, Outridge P, Poulain A, Poissant L, Rognerud S, Skov H, Søren Sørensen S, Wang F, Zdanowicz C. 2011. What is the fate of mercury entering the arctic environment? In Outridge $\mathrm{P}$, Dietz R, eds, AMAP Assessment 2011: Mercury in the Arctic. Arctic Monitoring and Assessment Programme (AMAP), Oslo, Norway, pp 45-65.

20. Munthe J, Goodsite M, Berg T, Chetelat J, Cole A, Dastoor A, Durnford D, Douglas T, Macdonald R, Muir D, Munthe J, Outridge P, Pacyna J, Ryzhkov A, Skov H, Steffen A, Sundseth K, Travnikov O, Wilson S, Wängberg I. 2011. Where does mercury in the arctic environment come from, and how does it get there? In Outridge P, Dietz R, eds, AMAP Assessment 2011: Mercury in the Arctic. Arctic Monitoring and Assessment Programme (AMAP), Oslo, Norway, pp 9-44.

21. Thiemann GW, Iverson SJ, Stirling I. 2008. Polar bear diets and arctic marine food webs: Insights from fatty acid analysis. Ecol Monogr 78: 591-613.

22. St. Louis VL, Derocher AE, Stirling I, Graydon JA, Lee C, Jocksch E, Richardson E, Ghorpade S, Kwan AK, Kirk JL, Lehnherr I, Swanson HK 2011. Differences in mercury bioaccumulation between polar bears (Ursus maritimus) from the Canadian high- and sub-Arctic. Environ Sci Technol 45:5922-5928.

23. McKinney MA, Letcher RJ, Aars J, Born EW, Branigan M, Dietz R, Evans TJ, Gabrielsen GW, Muir DCG, Peacock E, Sonne C. 2011. Regional contaminantion versus regional dietary differences: Understanding geographic variation in brominated and chlorinated contaminant levels in polar bears. Environ Sci Technol 45:896-902.

24. Derocher AE, Wiig O, Andersen M. 2002. Diet composition of polar bears in Svalbard and the western Barents Sea. Polar Biol 25:448-452.

25. Hobson KA. 1999. Tracing origins and migration of wildlife using stable isotopes: A review. Oecologia 120:314-326

26. Iverson SJ, Field C, Bowen DW, Blanchard W. 2004. Quantitative fatty acid signature analysis: A new method of estimating predator diets. Ecol Monogr 74:211-235.

27. Falk-Petersen S, Haug T, Hop H, Nilssen KT, Wold A. 2009. Transfer of lipids from plankton to blubber of harp and hooded seals off East Greenland. Deep-Sea Res 56:2080-2086.

28. Dalsgaard J, St. John M, Kattner G, Müller-Navarra D, Hagen W. 2003. Fatty acid trophic markers in the pelagic marine environment. Adv Mar Biol 46:225-340.

29. Jardine TD, Kidd KA, Fisk AT. 2006. Applications, considerations, and sources of uncertainty when using stable isotope analysis in ecotoxicology. Environ Sci Technol 40:7501-7511.

30. McKinney MA, Peacock E, Letcher RJ. 2009. Sea ice-associated diet change increases the levels of chlorinated and brominated contaminants in polar bears. Environ Sci Technol 43:4334-4339.

31. McKinney MA, Stirling I, Lunn NJ, Peacock E, Letcher RJ. 2010. The role of diet on long-term concentration and pattern trends of brominated and chlorinated contaminants in western Hudson Bay polar bears, 1991-2007. Sci Total Environ 408:6210-6222.
32. Loseto LL, Stern GA, Ferguson SH. 2008. Size and biomagnification: How habitat selection explains beluga mercury levels. Environ Sci Technol 42:3982-3988.

33. Calvert W, Ramsay MA. 1998. Evaluation of age determination of polar bears by counts of cementum growth layer groups. Ursus 10:449-453.

34. McKinney MA, Letcher R, Aars J, Born E, Branigan M, Dietz R, Evans T, Gabrielsen GW, Peacock E, Sonne C. 2011. Flame retardants and legacy contaminants in polar bears from Alaska, Canada, East Greenland and Svalbard, 2005-2008. Environ Int 37:365-374.

35. Hebert CE, Shutt JL, Hobson KA, Weseloh DVC. 1999. Spatial and temporal differences in the diet of Great Lakes herring gulls (Larus argentatus): Evidence from stable isotope analysis. Can J Fish Aquat Sci 56:323-338.

36. R Development Core Team. 2010. R: A language and environment for statistical computing, Ver 2.11.1. R Foundation for Statistical Computing, Vienna, Austria.

37. Greenacre M. 2007. Correspondence Analysis in Practice. Chapman \& Hall/CRC, London, UK.

38. Lebreton JD, Sabatier R. 1991. Principal component and correspondence analyses with respect to instrumental variables: An overview of their role in studies of structure-activity and species- environment relationships. In Devillers J, Karcher W, eds, Applied Multivariate Analysis in SAR and Environmental Studies. Kluwer Academic, Norwell, MA, USA pp 85-114.

39. Goñi MA, Yunker MB, Macdonald RW, Eglinton TI. 2000. Distribution and sources of organic biomarkers in arctic sediments from the Mackenzie River and Beaufort Shelf. Mar Chem 71:23-51.

40. Mundy CJ, Gosselin M, Starr M, Michel C. 2010. Riverine export and the effects of circulation on dissolved organic carbon in the Hudson Bay system, Canada. Limnol Oceanogr 55:315-323.

41. Hobson KA, Stirling I. 1997. Low variation in blood $\delta{ }^{13} \mathrm{C}$ among Hudson Bay polar bears: Implications for metabolism and tracing terrestrial foraging. Mar Mamm Sci 13:359-367.

42. Jones EP, Anderson LG, Jutterström S, Swift JH. 2008. Sources and distribution of fresh water in the East Greenland Current. Prog Oceanogr 78:37-44.

43. Hobson KA, Fisk A, Karnovsky N, Holst M, Gagnon J-M, Fortier M 2002. A stable isotope $(\delta 13 \mathrm{C}, \delta 15 \mathrm{~N})$ model for the North Water food web: Implications for evaluating trophodynamics and the flow of energy and contaminants. Deep Sea Res 49:5131-5150.

44. Hop H, Falk-Petersen S, Svendsen H, Kwasniewski S, Pavlov V, Pavlova O, Søreide JE. 2006. Physical and biological characteristics of the pelagic system across Fram Strait to Kongsfjorden. Prog Oceanogr 71:182-231.

45. Hopcroft RR, Clarke C, Nelson RJ, Raskoff KA. 2005. Zooplankton communities of the Arctic's Canada Basin: The contribution by smaller taxa. Polar Biol 28:198-206.

46. Harvey M, Therriault JC, Simard N. 2001. Hydrodynamic control of late summer species composition and abundance of zooplankton in Hudson Bay and Hudson Strait (Canada). J Plankton Res 23:481-496.

47. Hopcroft RR, Kosobokova KN, Pinchuk AI. 2010. Zooplankton community patterns in the Chukchi Sea during summer 2004. Deep Sea Res 57:27-39.

48. Leitch DR, Carrie J, Lean D, Macdonald RW, Stern GA, Wang F. 2007. The delivery of mercury to the Beaufort Sea of the Arctic Ocean by the Mackenzie River. Sci Total Environ 373:178-195.

49. Soreide JE, Leu E, Berge J, Graeve M, Falk-Petersen S. 2010. Timing of blooms, algal food quality and Calanus glacialis reproduction and growth in a changing Arctic. Global Change Biol 16:3154-3163.

50. Chaulk A, Stern GA, Armstrong D, Barber DG, Wang F. 2011. Mercury distribution and transport across the ocean-sea-ice-atmosphere interface in the Arctic Ocean. Environ Sci Technol 45:1866-1872.

51. Gailer J. 2007. Arsenic-selenium and mercury-selenium bonds in biology. Coord Chem Rev 251:234-254.

52. Dietz R, Riget F, Born EW. 2000. An assessment of selenium to mercury in Greenland marine animals. Sci Total Environ 245:15-24.

53. Anderson ORJ, Phillips RA, Shore RF, McGill RAR, McDonald RA Bearhop S. 2010. Element patterns in albatrosses and petrels: Influence of trophic position, foraging range, and prey type. Environ Pollut 158: 98-107.

54. Barwick M, Maher W. 2003. Biotransference and biomagnification of selenium copper, cadmium, zinc, arsenic and lead in a temperate seagrass ecosystem from Lake Macquarie Estuary, NSW, Australia. Mar Environ Res 56:471-502.

55. Campbell LM, Norstrom RJ, Hobson KA, Muir DCG, Backus S, Fisk AT. 2005. Mercury and other trace elements in a pelagic Arctic marine 
food web (Northwater Polynya, Baffin Bay). Sci Total Environ 351-352: 247-263.

56. Atwell L, Hobson KA, Welch HE. 1998. Biomagnification and bioaccumulation of mercury in an arctic marine food web: Insights from stable nitrogen isotope analysis. Can J Fish Aquat Sci 55:1114-1121.

57. Fujihara J, Kunito T, Kubota R, Tanabe S. 2003. Arsenic accumulation in livers of pinnipeds, seabirds and sea turtles: Subcellular distribution and interaction between arsenobetaine and glycine betaine. Comp Biochem Physiol C 136:287-296.

58. Graeve M, Kattner G, Wiencke C, Karsten U. 2002. Fatty acid composition of Arctic and Antarctic macroalgae: Indicator of phylogenetic and trophic relationships. Mar Ecol Progr Ser 231:67-74.

59. Riget F, Dietz R, Vorkamp K, Johansen P, Muir D. 2004. Levels and spatial and temporal trends of contaminants in Greenland biota: An updated review. Sci Total Environ 331:29-52.

60. Nielsen FH. 1998. Ultratrace elements in nutrition: Current knowledge and speculation. J Trace Elem Exp Med 11:251-274.

61. Andersson ME, Sommar J, Gårdfeldt K, Lindqvist O. 2008. Enhanced concentrations of dissolved gaseous mercury in the surface waters of the Arctic Ocean. Mar Chem 110:190-194.

62. Macdonald RW, Harner T, Fyfe J. 2005. Recent climate change in the Arctic and its impact on contaminant pathways and interpretation of temporal trend data. Sci Total Environ 342:5-86.

63. Kirk JL, Louis VLS, Hintelmann H, Lehnherr I, Else B, Poissant L. 2008. Methylated mercury species in marine waters of the Canadian high and sub Arctic. Environ Sci Technol 42:8367-8373.
64. Mason RP, Reinfelder JR, Morel FMM. 1996. Uptake, toxicity, and trophic transfer of mercury in a coastal diatom. Environ Sci Technol 30:1835-1845.

65. Horton TW, Blum JD, Xie ZQ, Hren M, Chamberlain CP. 2009. Stable isotope food-web analysis and mercury biomagnification in polar bears (Ursus maritimus). Polar Res 28:443-454.

66. Riget F, Moller P, Dietz R, Nielsen TG, Asmund G, Strand J, Larsen MM, Hobson KA. 2007. Transfer of mercury in the marine food web of West Greenland. J Environ Monit 9:877-883.

67. Hobson KA, Ambrose WG, Renaud PE. 1995. Sources of primary production, benthic-pelagic coupling, and trophic relationships within the Northeast Water Polynya: Insights from delta C-13 and delta N-15 analysis. Mar Ecol Progr Ser 128:1-10.

68. Pomerleau C, Winkler G, Sastri AR, Nelson RJ, Vagle S, Lesage V, Ferguson SH. 2011. Spatial patterns in zooplankton communities across the eastern Canadian sub-Arctic and Arctic waters: Insights from stable carbon (delta C-13) and nitrogen (delta N-15) isotope ratios. J Plankton Res 33:1779-1792.

69. McConnell JR, Edwards R. 2008. Coal burning leaves toxic heavy metal legacy in the Arctic. Proc Natl Acad Sci U S A 105:12140-12144.

70. Streets DG, Zhang Q, Wu Y. 2009. Projections of global mercury emissions in 2050. Environ Sci Technol 43:2983-2988.

71. Noyes PD, McElwee MK, Miller HD, Clark BW, Van Tiem LA, Walcott KC, Erwin KN, Levin ED. 2009. The toxicology of climate change: Environmental contaminants in a warming world. Environ Int 35: 971-986. 


\section{Supporting Information}

\section{Influence of Carbon and Lipid Sources on Variation of Mercury and Other Trace Elements in Polar Bears (Ursus maritimus)}

Heli Routti, $\dagger_{\dagger}^{*}$, Robert J. Letcher, $\dagger^{*}$ Erik W. Born, § Marsha Branigan, \| Rune Dietz, \# Thomas J. Evans, $\uparrow \dagger$ Melissa A. McKinney, $\dagger$ Elizabeth Peacock, $+\uparrow$ and Christian Sonne \#

$†$ Ecotoxicology and Wildlife Health Division, Science and Technology Branch, Environment Canada, National Wildlife Research Centre, Carleton University, Ottawa, Ontario, K1A 0H3, Canada

† Norwegian Polar Institute, Fram Centre, 9296 Troms $\emptyset$, Norway

§ Greenland Institute of Natural Resources, Nuuk DK-3900, Greenland

\| Department of Environment and Natural Resources, Government of the Northwest Territories, Inuvik, Northwest Territories X0E 0T0, Canada

\# Department of Bioscience, Faculty of Science and Technology, Aarhus University, Roskilde, DK-4000, Denmark

$\dagger \dagger$ United States Fish and Wildlife Service, Anchorage, Alaska 99503, U.S.A.

H+ Department of Environment, Government of Nunavut, Igloolik, Nunavut, X0A-0L0, Canada

* To whom correspondence should be addressed. Phone: +1 613-998-6696 (RJL)/+47 77750541 (HR). Fax: +1 613-998-0458 (RJL). E-mail: robert.letcher@ec.gc.ca (RJL)/heli.routti@npolar.no (HR) 
M.A. McKinney Current Addresses: Great Lakes Institute for Environmental Research, University of Windsor, Windsor, Ontario, N9B 3P4, Canada; Department of Biology, Dalhousie University, Halifax, Nova Scotia, B3H 4J1, Canada

E. Peacock Current address: US Geological Survey, Alaska Science Center, 4210 University Drive, Anchorage, Alaska 99508, USA. 


\section{MATERIALS AND METHODS}

Stable Carbon Isotope Analysis and Quality Control

All stable carbon isotope (SI) analysis were carried out by the Environmental Isotope Laboratory (EIL), University of Waterloo (Waterloo, ON, Canada), and have been described for the present polar bear muscle and other quality control samples [1,2]. Polar bear muscle tissues were homogenized, lipid-removed and prepared for analysis by standard protocols (e.g., ref [3]).

Solid polar bear muscle and necessary quality control samples were run for carbon analysis on one of 2 systems. The systems were either, 1) A Delta Plus Continuous Flow Stable Isotope Ratio Mass Spectrometer (Thermo Finnigan / Bremen-Germany) coupled to a Carlo Erba Elemental Analyzer (CHNS-O EA1108 - Italy), or 2) an Isochrom Continuous Flow Stable Isotope Ratio Mass Spectrometer (GVInstruments / Micromass-UK) coupled to a Carlo Erba Elemental Analyzer (CHNS-O EA1108 - Italy). The Micromass Isochrom EA-IRMS system was checked each day before analyzing samples for SIs by running the peak shape program. With the standard gas flowing, the mass spectrometer scanned from peak 43 to 47 . The operator checked to make sure the peak shape was correct and that the collectors were set in the center of the peaks. The standard was then introduced 10 times to check stability and reproducibility. If the reproducibility was less than 0.01 , the peak shape was adjusted and the standard check was repeated. The mass spectrometer sample run program performed an analysis on the gas standard with each sample to confirm stability. The performance of the complete sample was checked by the reproducibility of this analysis. 
For each group of 100 samples, standards were run to check and allow for bias and linearity corrections. Four replicates of different weights were placed at the beginning and end of each run. This set allowed for linearity corrections. Two sets of three or four replicates of NIST or EIL carbon standards were analyzed in each group. Two sets of replicates of element standards were also run in each group. EIL has accumulated a set of data on a number of NIST elemental standards with respect to their isotope content. This set of control standards was used to confirm that the EA is combusting and transporting gases with the correct isotope ratio to the mass spectrometer. A sample replicate is run at least every eight samples and duplicates were run from previous groups. The overall average number of repeats was about one every eight samples. A few sample replicates of different weights were analyzed to check linearity of the sample matrix. EIL recommended to establish a statistical population of 30 or more analysis of one sample to confirm the error associated with the natural variation of that sample type.

SI results were generally corrected to carbon standards IAEA-CH6 (sugar), EIL-72 (cellulose) and EIL-32 (graphite). The error for clean ball-milled standard material was $+/-0.2 \%$. This error was expected to increase depending on the homogeneity, type and amount of sample used in analysis. A truer representation of sample reproducibility was gained through sample repeats. Mean deviation of duplicate SI analysis on $10 \%$ of the polar bear samples was $0.07 \%$ or $\delta^{13} \mathrm{C}$. Standards were placed throughout each run at a range of weights to allow for an additional linearity correction, when necessary, due to machine fluctuations or samples of varying signal peak areas. Carbon compositions were calculated based on Carlo Erba Elemental Standards B2005, B2035 and B2036 with an error of $+/-1 \%$. Other NIST organic materials are run at EIL and cross-checked with other labs in hopes of producing a collection of organic reference 
materials for use in SI research. At present these materials were not used in correction but rather as monitoring material.

\section{Fatty Acids Analysis and Quality Control}

All fatty acid (FA) analysis for the polar bear fat and quality control samples were carried out by the Organic Contaminants Research Laboratory (OCRL) at NWRC and are described elsewhere [1,2]. Briefly, extraction and analysis of FAs was from 10-20 mg of inner adipose tissue of a collected polar bear sample, to avoid potentially oxidized outer tissue [4]. Lipids were extracted thrice using 2:1 $\mathrm{CHCl}_{3}: \mathrm{MeOH}$ [4] containing 0.01\% 2,6-di-t-butyl-4-methylphenol as antioxidant. 5- $\alpha$-Cholestane was used as internal standard. The extract was evaporated to dryness under $\mathrm{N}_{2}$, and lipid was redissolved in toluene. FAs were methylated via the Hilditch reagent [5]. After addition of $2 \% \mathrm{KHCO}_{3}$, the organic layer was collected and fatty acid methyl esters (FAMEs) were completely collected by two further extractions with hexane. FAMEs were analyzed by GC-FID equipped with a Supelco- 2560 bis-cyanopropyl column and quantified against a Supelco 37 component FAME external standard [6]. Here, we report only on the "dietary" FAs (i.e., those that are incorporated relatively unchanged from prey to predator adipose tissues for a monogastric predator) that were available for quantification based on the external standard. Each FAME was calculated as the \% of total dietary FAME.

Typical of FA analysis at NWRC (carried out by Lab Services and OCRL) Group personnel and students), a blank, duplicate and two reference materials, Great Lakes herring gull (Larus argentatus) egg pool and the NIST Pilot Whale blubber SRM1945, were extracted with every batch of 20 FA samples. Relative differences in duplicate analyses of polar bear and ringed seal samples were on average $6 \%$ and $7 \%$, respectively, for dietary FAs. The relative standard 
deviation (RSD) of dietary FAs averaged 6\% for the herring gull egg pool. SRM1945 dietary FA values were on average within 15\% RSD of our laboratory results from the 2007 NIST/NOAA Interlaboratory Comparison Exercise Program for Organic Contaminants in Marine Mammal Tissues. Recovery of 5- $\alpha$-chlolestane was $100 \pm 10 \%$.

\section{Mercury and Other Trace Metal and Element Analysis and Quality Control}

All trace element analysis of the present polar bear liver samples was carried out at the NWRC, Environment Canada, Carleton University and and are described elsewhere [7]. Liver samples were thawed, homogenized and then refrozen immediately at $-20{ }^{\circ} \mathrm{C}$. A thoroughly validated method used extensively at NWRC was used for total $\mathrm{Hg}$ determination in the liver samples. Briefly, freeze-dried and homogenized liver samples were analyzed for total $\mathrm{Hg}$ using DMA-80 Direct Mercury Analyzer (Milestone, Shelton, CT). The certified reference materials (CRMs) used for total Hg were Dolt-3 and Tort-2 (lobster hepatopancreas) from the National Research Council (NRC) of Canada and Oyster Tissue 1566b from National Institute of Standards Technology (NIST). To check for the homogeneity of total Hg in the samples, 22 random liver samples were analyzed in replicate. Replicates of the CRMs, Oyster Tissue 1566b, Dolt-3 and Tort- 2 were also analyzed to check calibration of the instrument, the within-run precision and the reproducibility of the method. Recoveries of Total $\mathrm{Hg}$ for the daily calibration check standards (CRMs Dolt-3, Tort-2 and Oyster Tissue 1566b) ranged from 83.0 to $111.4 \%$. Values obtained were within the acceptable limits. Standard deviations for all replicate readings for CRM samples were below 


\section{REFERENCE SECTION}

1. McKinney, M. A.; Peacock, E.; Letcher, R. J., Sea ice-associated diet change increases the levels of chlorinated and brominated contaminants in polar bears. Environ. Sci. Technol. 2009, 43, (12), 4334-4339.

2. McKinney, M. E.; Letcher, R. J.; Aars, J.; Born, E. W.; Branigan, M.; R., D.; Evans, T. J.; Gabrielsen, G. W.; Muir, D. C. G.; Peacock, E.; Sonne, C., Regional contaminantion versus regional dietary differences: understanding geographic variation in brominated and chlorinated contaminant levels in polar bears. Environ. Sci. Technol. 2011, 45, (3), 896902.

3. Hebert, C. E.; Shutt, J. L.; Hobson, K. A.; Weseloh, D. V. C. Spatial and temporal differences in the diet of Great Lakes herring gulls (Larus argentatus): evidence from stable isotope analysis. Can. J. Fish. Aquat. Sci. 1999, 56, 323-338.

4. Budge, S. M.; Iverson, S. J.; Koopman, H. N. Studying trophic ecology in marine ecosystems using fatty acids: a primer on analysis and interpretation. Mar. Mammal Sci. 2006, 22, 759-801.

5. Folch, J.; Lees, M.; Sloane-Stanley, G. H. A simple method for the isolation and purification of total lipids from animal tissues. J. Biol. Chem. 1957, 226, 497-509.

6. Hebert, C. E.; Arts, M. T.; Weseloh, D. V. C. Ecological tracers can quantify food web structure and change. Environ. Sci. Technol. 2006, 40, 5618-5623.

7. Routti, H.; Letcher, R.; Born, E. W.; Branigan, M.; Dietz, R.; Evans, T. J.; Fisk, A. T.; Peacock, E.; Sonne, C., Spatial and temporal trends of selected trace elements in liver tissue from polar bears (Ursus maritimus) from Alaska, Canada and Greenland. J. $\begin{array}{lllll}\text { Environ. } & \text { Monit. } & \text { 2011, } & 13, & \text { 2260-2267. }\end{array}$ 
Figure S1. Relationships between liver total $\mathrm{Hg}$, Se and As, and muscle $\delta^{15} \mathrm{~N}$ values in polar bears from ten subpopulations. Pearson correlations coefficients are shown.
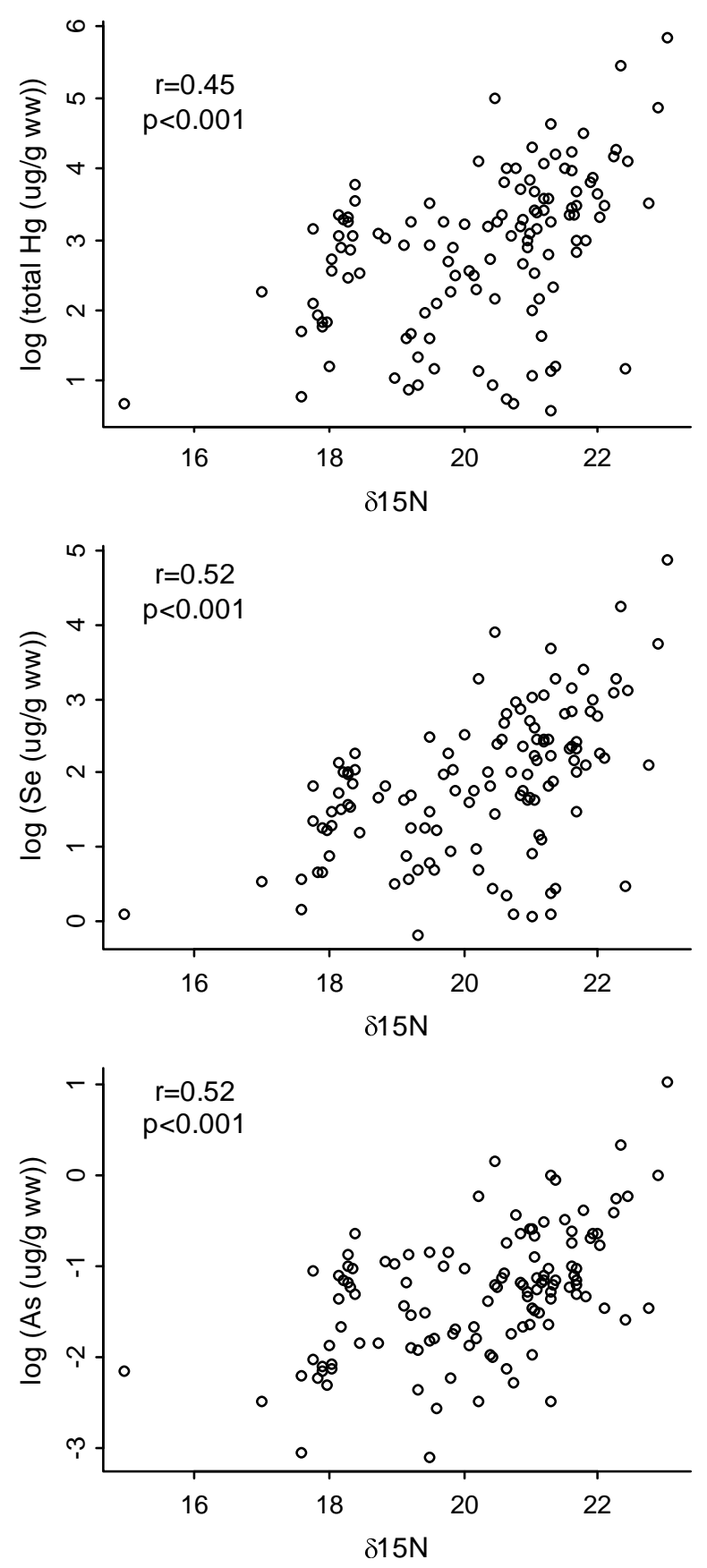